\title{
Adenomyoepithelioma with malignant transformation diagnosed by immunohistochemical analysis: case report
}

\author{
Adenomioepitelioma com transformações malignas diagnosticado por imuno-histoquímica: relato de caso \\ Claudia Rossetti'; Ligia Ajaime Azzalis²; Virginia Berlanga Campos Junqueira3; \\ Regina Maria Guidoni; ; Mara Regina Alcalá Gomes ${ }^{5}$; Fernando Luiz Affonso Fonseca ${ }^{6}$
}

\begin{abstract}
key words abstract
Adenomyoepithelioma

Adenomyoepitheliomas (AMEs) are rare breast lesions, which are characterized by the proliferation Breast of epithelial and myoepithelial cells. They are circumscribed lesions, which can be clinically and mammographically detected. However, when they are indistinctly limited, differential diagnosis Carcinoma with malignant lesions becomes difficult. In this paper, we report a case of adenomyoepithelioma with

Malignant malignant transformation of the myoepithelial component, a rare histological type that arises from the malignant transformation of epithelial, myoepithelial, or both elements. Its course and prognosis are uncertain. Mastectomy with sentinel lymph node biopsy followed by radiotherapy are the most effective treatment approaches.
\end{abstract}

\section{resumo}

Adenomioepiteliomas (AMEs) são lesões raras na mama, caracterizadas pela proliferação de elementos epiteliais e mioepiteliais. Clínica e mamograficamente apresentam-se como lesões bem delimitadas, que, quando assumem aspecto mal delimitado, tornam difícil o diagnóstico diferencial com lesões malignas. Relatamos um caso de AME com transformação maligna do componente mioepitelial, tipo histológico ainda mais raro, que surge da transformação maligna de elementos epiteliais, mioepiteliais ou ambos. Seu curso e seu prognóstico são incertos, contudo, mastectomia com pesquisa de linfonodo sentinela seguidos de radioterapia constituem a forma mais efetiva de tratamento. unitermos

Adenomioepitelioma

Mama

Carcinoma

Malignidade

1. Médica patologista; médica responsável pelo Serviço de Patologia da Mama da Faculdade de Medicina do ABC (FMABC).

2. Doutora em Bioquímica; professora adjunta do Departamento de Ciências Exatas e da Terra da Universidade Federal de São Paulo (UNIFESP, Diadema).

3. Livre-docente e professora titular do Departamento de Ciências Biológicas da UNIFESP (Diadema).

4. Médica patologista da FMABC.

5. Mastologista do Hospital Heliópolis.

6. Pós-doutor em Bioquímica Clínica; professor adjunto do Departamento de Ciências Biológicas da UNIFESP (Diadema); professor assistente do curso de Ciências Farmacêuticas da FMABC. 


\section{Introduction}

Breast acini and ducts are constituted by two cell populations in normal histology: an internal layer of epithelial cells, covered by an external layer of myoepithelial cells.

Breast adenomyoepitheliomas (AMEs) are unusual lesions, having been described for the first time by Hamperl, in 1970(4), and later classified by Tavassoli, in 1991(11), and are characterized by the proliferation of the two cell populations, epithelial and myoepithelial cells.

The age at which such lesions occur ranges from 26 to 82 years, with an average of around 60 years ${ }^{(11)}$.

They are presented as a unilateral mass, which can be isolated or accompanied by painless, precisely-limited satellite lesions, with occasional calcification foci.

In mammographies and ultrasound tests, they are normally precisely limited, although poorly defined peripheral aspects of infiltrative appearance may occur, making differential diagnoses with malignant lesions difficult.

AMEs represent a spectrum of injuries ranging from the purely AME benign AME with malignant transformation of either epithelial or myoepithelial component separately or even AME with malignant transformation of both components. The presence of calcifications is not common trait in this type of injury, but can be found ${ }^{(9)}$. May be associated with areas of adenosis, ductal hyperplasia or the aspect with papillary lesions and may also be associated with foci of metaplasia, whether cartilage, sebaceous or squamous or mucoepidermoid 3. These cases that exhibit aspects of malignant transformation are rare in the literature. Table shows the histological features found in AMEs and their classification.

\section{Case study}

Patient of 47 years referred three months previously with a nodular lesion on the right breast with imprecise limits, measuring $2.2 \times 1.4 \mathrm{~cm}$. In the mammogram, the lesion showed a precise outline, with foci of peripheral distortion at certain points. An excision was performed, followed by a peroperatory freeze test, but a conclusive diagnosis proved impossible. The material was sent for a histological examination in paraffin to better characterize the lesion.

\section{Results}

In histological terms, the lesion was characterized by the proliferation of epithelial and myoepithelial elements, with poorly defined limits, amid areas of sclerosing adenosis with papillary foci, with predominance of the myoepithelial

\section{Table Histological features found in adenomyoepitheliomas and their classification}

\begin{tabular}{|c|c|c|c|c|}
\hline Adenomyoepithelioma & Benign & $\begin{array}{l}\text { With malignant } \\
\text { transformation of } \\
\text { epithelial component }\end{array}$ & $\begin{array}{c}\text { With malignant } \\
\text { transformation of the } \\
\text { myoepithelial component }\end{array}$ & $\begin{array}{l}\text { With malignant } \\
\text { epithelial and } \\
\text { myoepithelial }\end{array}$ \\
\hline $\begin{array}{l}\text { Proliferation of epithelial and } \\
\text { myoepithelial elements }\end{array}$ & Presence & Presence & Presence & Presence \\
\hline $\begin{array}{l}\text { Anaplasia of epithelial } \\
\text { elements }\end{array}$ & Absent & Presence & Absent & Presence \\
\hline $\begin{array}{l}\text { Anaplasia of epithelial } \\
\text { elements }\end{array}$ & Absent & Absent & Presence & Presence \\
\hline Marked mitotic activity & Absent & $\begin{array}{l}\text { Presence in epythelial } \\
\text { component }\end{array}$ & $\begin{array}{l}\text { Presence in } \\
\text { myoephetelial } \\
\text { component }\end{array}$ & $\begin{array}{c}\text { Presence in both } \\
\text { components }\end{array}$ \\
\hline $\begin{array}{l}\text { CD10, P63, calponin, CK } \\
5 / 6\end{array}$ & Presence & Presence & Presence & Presence \\
\hline AE1/AE3, EMA & Presence & Presence & Presence & Presence \\
\hline KI 67 (MIB 1) & Absent & Presence in epythelial & $\begin{array}{l}\text { Presence in } \\
\text { myoephitelial }\end{array}$ & $\begin{array}{l}\text { Presence in } \\
\text { epythelial and } \\
\text { myiophitelial }\end{array}$ \\
\hline
\end{tabular}

EMA: ephitelial membrane antigen; CK: cytokeratin. 
component, which was constituted by cells with vacuolated, extensive cytoplasm, with the presence of nuclear atypias, characterized by irregular nuclei, coarse chromatin, evident nucleolus and frequent mitoses, sometimes with the development of solid blocks of the myoepithelial component (Figure 1). The epithelial component showed nuclear anaplasia, with karyomegaly, evident nucleolus and mitotic figures, less evident, however, than with the myoepithelial elements.

A immunohistochemical study was carried out with markers for myoepithelial cells (P63 and calponin) (Figure 2) and epithelial elements (AE1/AE3) (Figure 3 with evaluation of the cell proliferation index using the KI 67 marker, for subsequent mitotic counting, with the identification of up to 37 mitoses for 10 fields of large increase, in both components (Figure 4).

The diagnosis was AME with malignant transformation of the myoepithelial component, and the surgical margins coincided with the lesion.

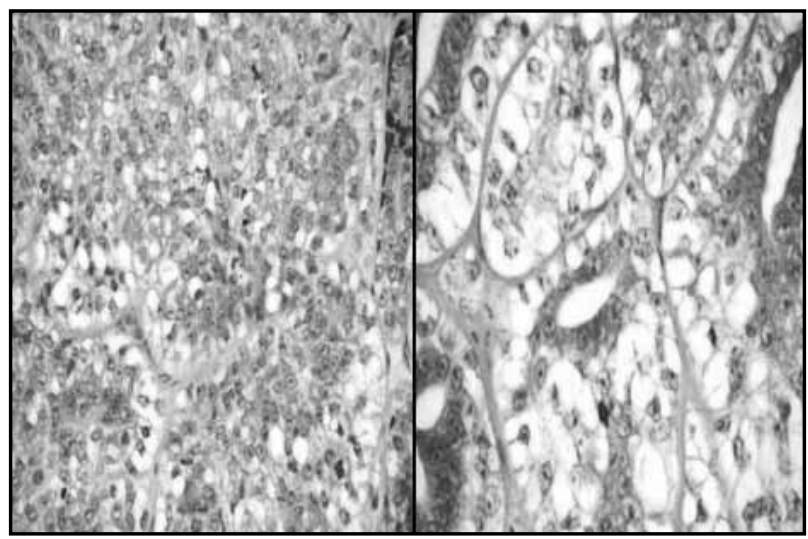

Figure 1 - Proliferation of epithelial and myoepithelial elements, the second with intense anaplasia (HE 400x)

HE: hematoxylin and eosin.

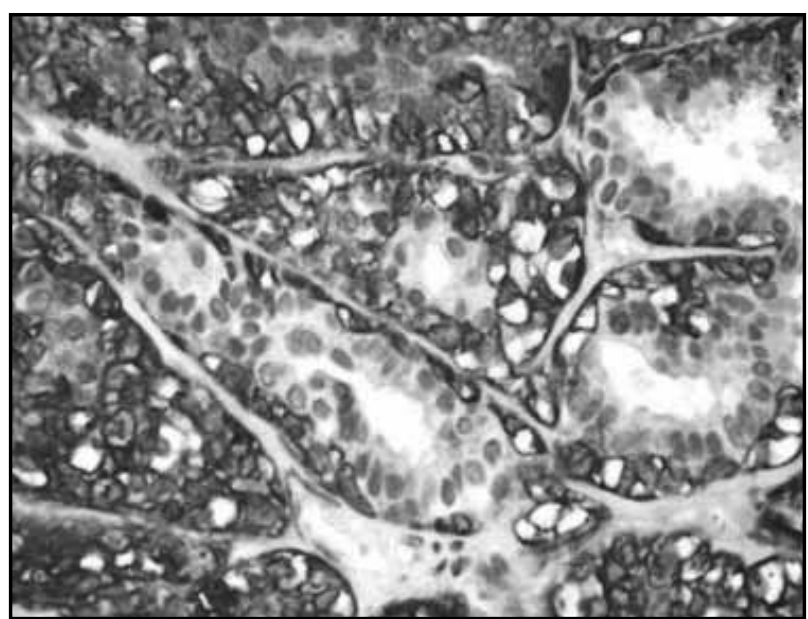

Figure 2 - Positive reaction to the calponin marker in myoepithelial cells (IHQ 400X) IHQ: immunohistochemical.

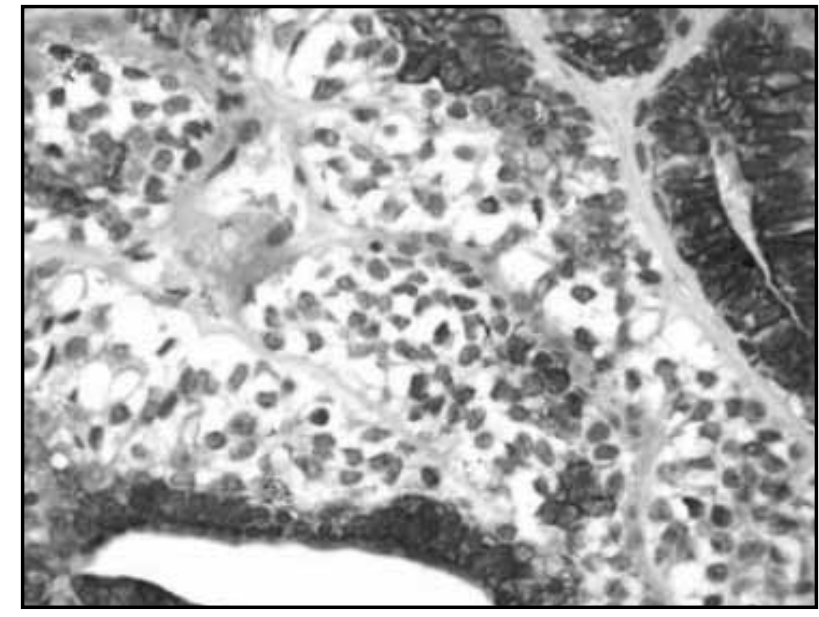

Figure 3 - Positive reaction to the AE1/AE3 marker in epithelial cells (IHQ 400X) IHQ: immunohistochemical.

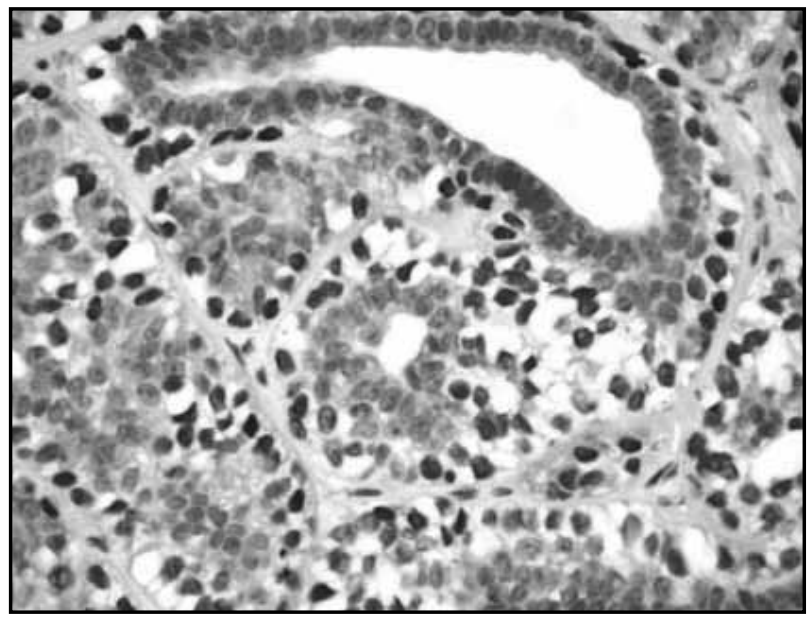

Figure 4 - Positive reaction to the KI 67 cell proliferation marker (IHQ 400x) IHQ: immunohistochemical.

A Madden mastectomy ${ }^{(6)}$ and biopsy of the sentinel lymph node were performed, with histological identification of only rare foci of hyperplasia of myoepithelial cells in rare acini and ducts. Neoplastic lymph node lesions were not identified even after 50-micron serial sections.

\section{Discussion}

AMEs are rare lesions, only 27 cases having been described in the literature ${ }^{(2,7,9,11)}$.

They usually appear as nodular lesions with precise limits, sometimes exhibiting a cystic appearance in the mammographic test ${ }^{(9)}$, affecting women from 26 to 82 years of age ${ }^{(9)}$, with no preference for the right or the left breast.

Macroscopically, they can vary from 0.5 to $8 \mathrm{~cm}$, with an average size of $2.5 \mathrm{~cm}$, usually described as well-limited, firm, white-yellowish nodes, which can, however, present poorly 
defined limits, especially in mammographic tests, making it difficult to differentiate them from malignant lesions.

Microscopically, they have the appearance of aggregate nodes, being considered by a minority of authors as papilloma variants, but can originate in areas of lobular and adenose proliferation.

They are constituted by the proliferation of epithelial and myoepithelial elements, often exhibiting focal papillary growth, with immunohistochemical positivity for epithelial markers, such as carcininoembrionary antigen (CEA) and AE1/AE3 for calponin, P63, CD10, S100, and cytokeratins 5 and 14 for myoepithelial cells $s^{(3,5)}$.

Myoepithelial cells may assume a polygonal or fusiform aspect in their peripheral aspects.

As for their histological classification, according to Tavassoli ${ }^{(11)}$, they can take tubular, fusiform or trabecular form. Squamous or cartilaginous metaplasia may also be present ${ }^{(9)}$.

Malignant characteristics in AMEs result in malignant AME, and these cases are exceedingly rare in the literature ${ }^{(2,9-11)}$. The malignant transformation can occur in epithelial elements, myoepithelial elements or both.

Histologically, the criteria for malignancy are not yet clearly defined, but include irregular outlines, with a marginal infiltrative aspect, cellular pleomorphism and atypia, the presence of necrosis and high mitotic index, excessive epithelial and myoepithelial growth and peripheral invasive aspects.

Mammographically, they can have a totally benign aspect, but there are cases in which it is difficult to differentiate them from malignant lesions ${ }^{(10)}$.

The immunohistochemical study assists in the presence of positive staining for epithelial elements through positive for AE1/AE3 and epithelial membrane antigen (EMA) positivity and concomitant injury to myoepithelial elements with positive staining with P63, calponin, CD10 and cytokeratin $5 / 6$, associated with histologic proliferation of both elements ${ }^{(9,12)}$. Already in the case of malignant variant, the use of marker KI67 (MIB 1) has aided in the identification of mitotic figures, typical of this injury spectrum.

In cases of a malignant component, treatment consists of a complete excision of the lesion. This is imperative, given the tendency of relapse even in the benign forms. Treatment consists of the complete excision of the lesion, mostly through mastectomy with biopsy of the sentinel lymph node, since the literature reports cases of distance metastasis even in benign forms of AMEs. Even when they are characterized as benign lesions, the literature reports occurrences of metastases, especially in the lungs, usually associated with lesions larger than $2 \mathrm{~cm}^{(1,8)}$. Prognosis is therefore uncertain.

Local recurrence is frequent, so the complete excision of the lesion is mandatory. Treatment consists of the excision of the lesion with precisely free margins, with the biopsy of a possible metastasis to lymph nodes in cases of malignant transformation. Apparently, these lesions do not respond well to chemotherapy, therefore, radiotherapy is better indicated.

\section{Conclusion}

Adding the histological aspects identified in the lesion to the clinical aspect and the immunohistochemical profile, with a positive reaction to epithelial and myoepithelial markers in the lesion associated with anaplasia, cellular pleomorphism and high mitotic index, we concluded that we were dealing with an AME with malignant transformation of the epithelial and myoepithelial components.

\section{References}

1. AHMED, A. A.; HELLER, D. S. Malignant adenomyoepitelioma of the breast with malignant proliferation of epithelial and myoepithelial elements: a case report and review of the literature. Arch Pathol Lab Med, v. 124, n. 4 , p. 632-6, 2000.

2. CHUN, Y. H. et al. Adenomyoepithelioma of the breast. Tumori, v. 93, p. 493-5, 2007.

3. GATTI, G. et al. Adenomyoepithelioma of the breast, presenting as a cancer. Adenomyoepithelioma of the breast, presenting as a cancer. Tumori, v. 90, n. 3, p. 337-9, 2004.

4. HAMPERL, H. The myoepithelia (myoepithelial cells): normal state; regressive changes; hiperplasia; tumors. Curr Top Pathol, v. 53, p. 161-213, 1970.

5. HAN, B. et al. Myoepithelial carcinoma arising in an adenomyoepiteliom of the breast: case report with immunohistochemical and mutational analysis. Pathol Int, v. 56, n. 4, p. 211-6, 2005. 
6. MADDEN, J. L.; KANDALAFT, S.; BOURQUE, R. A. Modified darical mastectomy. Prensa Med Argent, v. 57, n. 29, p. 1421-3, 1970.

7. MCLAREN, B. K. et al. Adenomyoepithelioma: clinical, histologic, and immunohistologic evaluation of a series of related lesions. Am J Surg Pathol, v. 29, n. 10, p. 1294-9, 2005.

8. NADELMAN, C. M.; LESLIE, K. O.; FISHBEIN, M. C. Benign, metastasizing adenomyoepithelioma of the breast: a report of 2 cases. Arch Pathol Lab Med, v. 130, n. 9, p. 1349-53, 2006.

9. ROSEN, P. P. Myoepithelial neoplasmas. In: ROSEN, P. P. Rosen's breast pathology. $3^{\text {rd }}$ ed. Philadelphia: Lippincott Williams \& Wilkins, 2009. p. 137-59.
10. RUIZ-DELGADO, M. L. et al. Benign adenomyoepithelioma of the breast: imagining findings mimicking malignancy and histopathological features. Acta Radiol, v. 48, n. 1, p. 27-9, 2007.

11. TAVASSOLI, F. A. Myoepithelial lesions of the breast. Myoepitheliosis, adenomyoepithelioma, and myoepithelial carcinoma. Am J Surg Pathol, v. 15, n. 6, p. 554-68, 1991.

12. VAN DORPE, J. et al. Malignant myoepithelioma of the breast. Case report with immunohistochemical study. Arch Anat Cutol Pathol, v. 44, p. 193-8, 1996.

\section{Mailing address}

Fernando Luiz Affonso Fonseca Laboratório de Análises Clínicas da FMABC Av. Príncipe de Gales, 821 CEP: 09060-650 - Santo André-SP e-mail: fon_fonseca@yahoo.com.br 